Article

\title{
A Retrospective, Cross-sectional Hospital-based Study to De- termine the Epidemiological, Clinical and Comorbidity Charac- teristics in Older Adults with Psoriasis
}

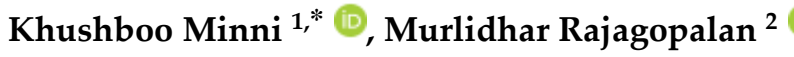 \\ ${ }^{1}$ Department of Dermatology, Venereology and Leprosy, K.J. Somaiya Medical College and Research Centre, \\ Mumbai, Maharashtra, India \\ 2 Department of Dermatology, Apollo Hospital, Chennai, Tamil Nadu, India \\ *Correspondence: drkhushboominni@gmail.com
}

How to cite this paper: Minni, K., \& Rajagopalan, M. (2022). A Retrospective, Cross-sectional Hospital-based Study to Determine the Epidemiological, Clinical and Comorbidity Characteristics in Older Adults with Psoriasis. Global Journal of Epidemiology and Infectious Disease, 2(1), 4-18. Retrieved from https://www.scipublications.com/journal/index.php/gjeid/article/view/182

\begin{abstract}
Background: Psoriasis is extensively studied among middle-aged adults, but not many have studied psoriasis in older adults(geriatrics). Objectives: To analyze epidemiological, clinical, comorbidities and therapeutic profile of geriatric psoriasis(GP). Methods: All consenting clinically diagnosed psoriatic patients $\geq 60$ years were divided into two groups: Elderly psoriatic(EP)(60-75 years) and Ultra elderly psoriatic(UP)(>75 years). The dermatologist filled their clinical characteristics' standardised questionnaire to determine comorbidities, drug interactions profile and compared with age-matched controls using Chi square test. Results: Prevalence of GP is 14.5\%(Average age:68 years; Sex ratio=2.5:1) among geriatrics attending dermatology OPD. Most common(49.9\%) as well as initial site affected(39.3\%) were Palms \pm Soles. Nummular plaque $(90.2 \%)$ was most common type. Superficial fungal infection(26.9\%) and pruritus $(90.8 \%)$ were commonly associated cutaneous disease and symptom $(\mathrm{p}<0.05)$ respectively. Hypertension $(49.7 \%)$, Diabetes Mellitus $(22.8 \%)$, dyslipidemia(25.8\%) and Metabolic syndrome(MS)(17.8\%) were associated systemic comorbidities. Dyslipidemia and MS(p<0.0001) were more common among GP(163) than controls(963). Drug aggravated psoriasis could not be linked to polypharmacy. Although, topicals were mainstay, oral Methotrexate was most efficacious systemically. Conclusion: Our findings suggest a trimodal age of psoriasis onset at 68 years. As age advances, psoriasis severity decreases, unstable guttate lesions decrease; palms \pm soles commonly involved; infrequent familial occurrence with Polypharmacy not aggravating psoriasis. Active screening for cardiovascular comorbidities in all geriatric psoriasis patients is highly recommended.
\end{abstract}

Received: November 09, 2021 Accepted: February 08, 2022 Published: February 10, 2022

\section{Keywords: Psoriasis, Elderly, Comorbidities, Geriatric psoriasis, Ultra elderly}

\section{Introduction}

Indian Government's 'National Policy on Older Persons' defines 'senior citizen/gerCopyright: () 2022 by the authors. Submitted for possible open access publication under the terms and conditions of the Creative Commons Attribution (CC BY) license (http://creativecommons.org/licenses /by/4.0/). rise from $8 \%(2015)$ to $19 \%$ (2050) [2]. About $4.9 \%$ of patients had psoriatic onset after 60 years of age and the proportion might increase in aging society [3]. Many Indian studies describe psoriasis epidemiology[4-11] in adults, but none have outlined specific epidemiological trends of psoriasis in geriatric Indian population. This contributes to the underestimation of age-related psoriatic problems.

Our study aimed to analyze the prevalence of Geriatric Psoriasis(GP) and to identify its specific epidemiological, clinical, comorbidity and therapeutic trends.

\section{Material and Methods}


A retrospective, outpatient, tertiary hospital-based, cross-sectional study was conducted to include patients $\geq 60$ years (geriatics) with self-reported dermatosis between $1^{\text {st }}$ June 2020 to 31st May 2021. They were arbitrarily divided into groups of 'Elderly:60-75 years' and 'Ultra elderly:>75 years', as no such division is defined in Indian population [1]. (Figure 1) Inclusion criteria involved the subject to be of an appropriate age, maintain verbal contact for medical history and allow examination. Psoriasis being easily diagnosed clinically, diagnostic tests were performed only when necessary [12]. Cases with doubtful diagnosis, refusing biopsy and denying informed written consent were excluded.

\begin{tabular}{|l|l|l|l|}
\hline Psoriasis & $\begin{array}{l}\text { Elderly(60-75 } \\
\text { years) }\end{array}$ & $\begin{array}{l}\text { Ultraelderly( } \geq \mathbf{7 5} \\
\text { years) }\end{array}$ & Total \\
\hline Present & $141(16.6 \%)$ & $22(7.9 \%)$ & $163(14.5 \%)($ Cases $)$ \\
\hline Absent & $707(83.4 \%)$ & $256(92.1 \%)$ & $963(85.5 \%)($ Controls $)$ \\
\hline Total & $848(75.3 \%)$ & $278(24.7 \%)$ & $1126(100 \%)$ \\
\hline
\end{tabular}

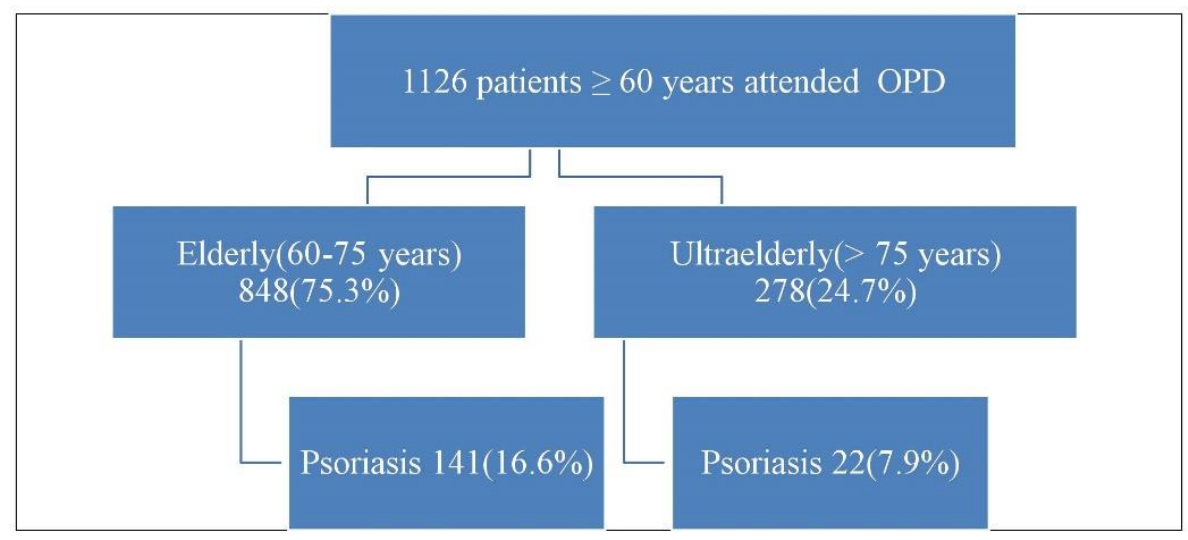

Figure 1. Prevalence of Psoriasis in patients $>60$ years with self-reported dermatosis.

\subsection{Study design}

All demographic and medical information was recorded using a psoriasis questionnaire, evaluated and filled by an independent dermatologist to record patients' demographics; habits; triggers, pruritus, detailed Psoriasis onset, duration, site, disease course, severity, Psoriasis Area Severity Index(PASI), triggers, and/or previous/current systemic treatment with PASI 75 response, side effects, drug interactions or any other concomitant skin or systemic comorbidity and management for patients attending our Psoriasis clinic.

Systemic comorbidities were compared with geriatrics having other self-reported dermatosis(except psoriasis) as controls. The relationship between these comorbidities and clinical characteristics of psoriasis were investigated.

\subsection{Statistical analyses}

Categorical variables were presented as numbers, percentages; Odd's ratio and Chi square tests used for comparison of proportions with $\mathrm{p}<0.05$ as test of significance on MedCalc for Windows, version 19.4.1(Med Calc Software, Ostend, Belgium) using twotailed tests.

\section{Results}

\subsection{Demographic data}

A total of 1126 patients $\geq 60$ years with self-reported dermatosis(60-88 years) attended our department; of which $163(14.5 \%$ ) had psoriasis; average:67 \pm 5.94 years with confidence 
interval(CI 95\%) 66-68. They were divided into 'Elderly Psoriatics(EP)' and 'Ultraelderly Psoriatics(UP)' with a median age of 65 and 78 years respectively.(Figure 1) Both groups were comparable for their baseline characteristics. (Table 1)

Table 1. Demographic profile of Geriatric Psoriatic patients.

\begin{tabular}{|c|c|c|c|c|c|c|c|c|c|c|}
\hline $\begin{array}{l}\text { Sr. } \\
\text { No. }\end{array}$ & \multirow{2}{*}{\multicolumn{2}{|c|}{ Characteristics }} & \multicolumn{2}{|c|}{$\begin{array}{c}\text { Elderly }(60-75 \\
\text { years) }\end{array}$} & \multicolumn{2}{|c|}{$\begin{array}{l}\text { Ultraelderly }(> \\
75 \text { years }\end{array}$} & \multirow[t]{2}{*}{$\begin{array}{c}\mathrm{P} \text { value }(\mathrm{p}< \\
0.05)\end{array}$} & \multirow[t]{2}{*}{$x^{2}$} & \multicolumn{2}{|c|}{$\begin{array}{l}\text { Grand to- } \\
\text { tal }\end{array}$} \\
\hline & & & Freq & $\%$ & Freq & $\%$ & & & Freq & $\%$ \\
\hline \multirow[t]{3}{*}{1} & \multirow[t]{3}{*}{ Gender } & Males & 102 & 72.3 & 14 & 63.6 & \multirow[t]{3}{*}{0.4} & \multirow[t]{3}{*}{0.7} & 116 & 71.2 \\
\hline & & Females & 39 & 27.3 & 8 & 36.4 & & & 47 & 28.8 \\
\hline & & Total & 141 & 86.5 & 22 & 13.5 & & & 163 & 100 \\
\hline \multirow[t]{4}{*}{2} & \multirow[t]{4}{*}{ Body Mass Index (BMI $)^{43}$} & $\begin{array}{l}\text { Underweight }(<18.5 \\
\qquad \mathrm{kg} / \mathrm{m} 2)\end{array}$ & 2 & 1.4 & 3 & 13.6 & \multirow[t]{4}{*}{0.00055} & \multirow[t]{4}{*}{17.52} & 5 & 3.1 \\
\hline & & $\begin{array}{l}\text { Normal or lean(18.5- } \\
22.9 \mathrm{~kg} / \mathrm{m} 2)\end{array}$ & 17 & 12.1 & 5 & 22.7 & & & 22 & 13.5 \\
\hline & & $\begin{array}{c}\text { Overweight }(23.0-24.9 \\
\mathrm{kg} / \mathrm{m} 2)\end{array}$ & 78 & 55.3 & 10 & 45.5 & & & 88 & 54.0 \\
\hline & & Obese $(\geq 25$ kg/m2) & 44 & 31.2 & 4 & 18.2 & & & 48 & 29.4 \\
\hline \multirow[t]{2}{*}{3} & \multirow[t]{2}{*}{ Duration since Psoriasis onset } & $<10$ years & 112 & 79.43 & 15 & 68.2 & \multirow[t]{2}{*}{0.07} & \multirow[t]{2}{*}{3.2} & 127 & 77.9 \\
\hline & & $\geq 10$ years & 29 & 20.57 & 7 & 31.8 & & & 36 & 22.1 \\
\hline \multirow[t]{3}{*}{4} & \multirow{3}{*}{$\begin{array}{l}\text { First Visit to the Dermatologist for manage- } \\
\text { ment after Psoriasis onset within }\end{array}$} & $<6$ months & 126 & 89.36 & 22 & 100 & \multirow[t]{3}{*}{0.28} & \multirow[t]{3}{*}{2.58} & 148 & 90.8 \\
\hline & & 6 months- 2 years & 9 & 6.38 & 0 & 0 & & & 9 & \\
\hline & & $>2$ years & 6 & 4.26 & 0 & 0 & & & 6 & \\
\hline \multirow[t]{2}{*}{5} & \multirow[t]{2}{*}{ Associated skin disorder } & Yes & 47 & 33.3 & 7 & 31.8 & \multirow[t]{2}{*}{0.88} & \multirow[t]{2}{*}{0.02} & 54 & 33.1 \\
\hline & & No & 94 & 66.7 & 15 & 69.2 & & & 109 & 67.9 \\
\hline \multirow[t]{4}{*}{6} & \multirow[t]{4}{*}{ Habits } & Smoking & 29 & 20.6 & 4 & 18.2 & \multirow[t]{4}{*}{0.125} & \multirow[t]{4}{*}{4.15} & 33 & 20.3 \\
\hline & & Alcoholism & 17 & 12.1 & 1 & 4.5 & & & 18 & 11 \\
\hline & & Tobacco & 30 & 21.3 & 6 & 27.3 & & & 36 & 22.1 \\
\hline & & Others & 0 & 0 & 0 & 0 & & & 0 & 0 \\
\hline
\end{tabular}


Inspite of a significant difference $(\mathrm{p}<0.05)$ between body weights of both groups, no significant relationship could be established between Body Mass Index, psoriasis duration and severity(PASI). Tobacco and alcoholism were most prevalent.

About one third of GP had concomitant other skin disorders. Superficial fungal infections $(26.9 \%)$,eczema(5.52\%), nail $(4.29 \%)$ and hyperpigmentary disorders $(3.68 \%)$ were most common.

\subsection{Clinical Characteristics}

Nummular Plaque Psoriasis(NPP)(90.18\%) was most common GP phenotype. Seven $(5 \%)$ EP presented with guttate lesions while none in $\mathrm{UP}(\mathrm{p}<0.05)$. (Table 2$)$

Table 2. Clinical characteristics of geriatric psoriasis.

\begin{tabular}{|c|c|c|c|c|c|c|c|c|c|c|c|}
\hline \multirow[t]{2}{*}{$\begin{array}{l}\text { Sr. } \\
\text { No. }\end{array}$} & & \multirow{2}{*}{\multicolumn{2}{|c|}{ Characteristics }} & \multicolumn{2}{|c|}{$\begin{array}{c}\text { Elderly (60-75 } \\
\text { years) }\end{array}$} & \multicolumn{2}{|c|}{$\begin{array}{c}\text { Ultraelderly }(> \\
75 \text { years }\end{array}$} & \multirow[t]{2}{*}{$\begin{array}{l}P \text { value }(\mathrm{p} \\
\quad<0.05)\end{array}$} & \multirow[t]{2}{*}{$x^{2}$} & \multicolumn{2}{|c|}{$\begin{array}{l}\text { Grand to- } \\
\quad \text { tal }\end{array}$} \\
\hline & & & & Freq & $\%$ & Freq & $\%$ & & & Freq & $\%$ \\
\hline \multirow[t]{6}{*}{1} & \multirow[t]{6}{*}{$\begin{array}{l}\text { Morphological } \\
\text { type of psoriasis }\end{array}$} & \multirow[t]{2}{*}{$\begin{array}{l}\text { Chronic } \\
\text { plaque } \\
\text { psoriasis }\end{array}$} & Nummular plaque $(1-5 \mathrm{~cm})$ & 127 & 90.1 & 20 & 90.9 & 0.95 & 0.003 & 147 & 90.2 \\
\hline & & & Large plaque $(>5 \mathrm{~cm})$ & 9 & 6.4 & 2 & 9.1 & 0.48 & 0.48 & 11 & 6.8 \\
\hline & & & Guttate $(<1 \mathrm{~cm})$ & 7 & 5 & 0 & 0 & 0.02 & 4.96 & 7 & 4.3 \\
\hline & & & Pustular & 2 & 1.4 & 0 & 0 & 0.23 & 1.42 & 2 & 1.2 \\
\hline & & & Erythrodermic & 1 & 0.7 & 0 & 0 & 0.39 & 0.71 & 1 & 0.6 \\
\hline & & & Others & 4 & 2.8 & 0 & 0 & 0.09 & 2.84 & 4 & 2.45 \\
\hline \multirow[t]{2}{*}{2} & \multirow[t]{2}{*}{ Nails involved } & & Yes & 53 & 37.6 & 11 & 50 & \multirow[t]{2}{*}{0.07} & \multirow[t]{2}{*}{3.12} & 64 & 39.3 \\
\hline & & & No & 88 & 62.4 & 11 & 50 & & & 99 & 60.7 \\
\hline 3 & \multicolumn{3}{|c|}{ Psoriatic arthritis } & 0 & 0 & 0 & 0 & & & 0 & 0 \\
\hline
\end{tabular}

Palms \pm Soles were most common initial site of GP onset(43.6\%) along with most common site affected overall( $49.9 \%)$. There was a significant difference amongst back and palms \pm soles affection in both groups $(p=0.0001, p<0.05)$. (Figure 2$)$ 


\section{Sites affected in Geriatric Psoriasis}

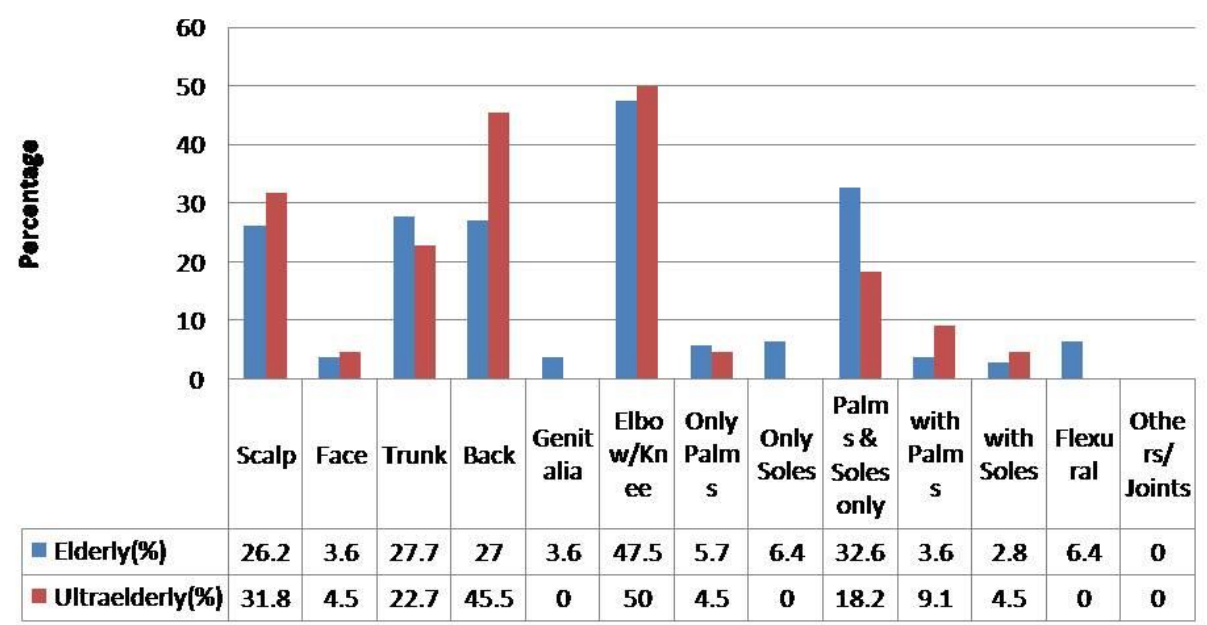

Figure 2. Sites affected in Geriatric Psoriasis.

Nails were involved in 26(49.1\%)EP and 7(63.6\%)UP with $>1$ psoriatic nail changes being present in 33(51.6\%). Pitting(98.4\%), Onycholysis(23.4\%) and Subungual hyperkeratoisis(17.2\%) were most common nail changes.

Common GP triggers, subjective pruritus and improvement over 6 months are described in Table 3.

Table 3. Geriatric psoriasis and its relation to common triggers, pruritus and subjective improvement.

\begin{tabular}{|c|c|c|c|c|c|c|c|c|c|c|}
\hline $\begin{array}{l}\text { Sr. } \\
\text { No. }\end{array}$ & \multirow{2}{*}{\multicolumn{2}{|c|}{ Characteristics }} & \multicolumn{2}{|c|}{$\begin{array}{c}\text { Elderly }(60-75 \\
\text { years })\end{array}$} & \multicolumn{2}{|c|}{$\begin{array}{l}\text { Ultraelderly }(>75 \\
\text { years }\end{array}$} & \multirow[t]{2}{*}{$\begin{array}{c}\mathrm{P} \text { value }(\mathrm{p}< \\
0.05)\end{array}$} & \multirow[t]{2}{*}{$x^{2}$} & \multicolumn{2}{|c|}{$\begin{array}{l}\text { Grand to- } \\
\quad \text { tal }\end{array}$} \\
\hline & & & Freq & $\%$ & Freq & $\%$ & & & Freq & $\%$ \\
\hline 1. & Triggers & & & & & & & & & \\
\hline a. & $\begin{array}{l}\text { Family history of Psoriasis }\left(1^{\text {st }} \text { de- }\right. \\
\text { gree })\end{array}$ & Yes & 10 & 7.1 & 0 & 0 & 0.007 & 7.1 & 10 & 6.13 \\
\hline b. & Mental Stress & Yes & 59 & 41.8 & 4 & 18.2 & 0.002 & 9.28 & 63 & 38.65 \\
\hline c. & Seasonal exacerbation & Yes & 66 & 46.8 & 11 & 50 & 0.74 & 0.105 & 77 & 47.24 \\
\hline d. & Psoroatopic(presence of atopy) & Yes & 15 & 10.6 & 3 & 13.64 & 0.53 & 0.381 & 18 & 11.04 \\
\hline e. & $\begin{array}{l}\text { Seboatopic(predominant sebor- } \\
\text { rhoeic involvement) }\end{array}$ & Yes & 15 & 10.6 & 3 & 13.64 & 0.53 & 0.381 & 18 & 11.04 \\
\hline f. & Drug exacerbation & Yes & 0 & 0 & 0 & 0 & & & 0 & 0 \\
\hline g. & Non-compliant exacerbation & Yes & 38 & 27 & 4 & 18.2 & 0.19 & 1.71 & 42 & 25.8 \\
\hline 2 & Associated pruritus & None & 11 & 7.8 & 4 & 18.2 & 0.04 & 4.16 & 15 & 9.2 \\
\hline
\end{tabular}




\begin{tabular}{|c|c|c|c|c|c|c|c|c|c|c|}
\hline & & Mild & 91 & 64.5 & 14 & 63.6 & 0.93 & 0.006 & 105 & 64.4 \\
\hline & & Moderate & 38 & 27 & 3 & 13.6 & 0.04 & 4.42 & 41 & 25.2 \\
\hline & & Severe & 1 & 0.7 & 1 & 4.6 & 0.09 & 2.86 & 2 & 1.2 \\
\hline \multirow[t]{4}{*}{3} & \multirow[t]{4}{*}{ Subjective sensation in last 6 months } & Improved & 82 & 58.2 & 8 & 36.4 & 0.02 & 5.02 & 90 & 55.2 \\
\hline & & Stationary & 7 & 5 & 1 & 4.6 & 0.89 & 0.016 & 8 & 5 \\
\hline & & $\begin{array}{c}\text { Wax and } \\
\text { Wane }\end{array}$ & 32 & 22.7 & 6 & 27.3 & 0.5 & 0.42 & 38 & 23.3 \\
\hline & & Aggravated & 20 & 14.1 & 3 & 13.6 & 0.9 & 0.009 & 23 & 14.1 \\
\hline
\end{tabular}

Mild psoriasis(92.6\%) was most common among both groups while moderate/severe psoriasis was seen in $12(7.4 \%)$ according to PASI.

Although GP severity was mild, systemic therapy was required in $66(46.8 \%)$ EP vs $3(13.6 \%)$ UP ( $p=0.0003$ ). As monotherapy, $52.2 \%, 56.5 \%, 50 \%, 61.9 \%$ and $66.7 \%$ of EP started on Apremilast, oral Methotrexate, injectable Methotrexate, Acitretin and Cyclosporine respectively attained PASI 75. Apremilast, injectable Methotrexate and Cyclosporine were not used in UP. (Figure 3)

\section{Efficacy of systemic therapy in Geriatric psoriasis}

\begin{tabular}{|l|c|c|c|c|c|}
\hline & \multicolumn{1}{c|}{$\begin{array}{c}14 \\
12\end{array}$} \\
\hline
\end{tabular}

Figure 3. Efficacy of systemic therapy in Geriatric Psoriasis.

\subsection{Systemic Comorbidity and Geriatric Psoriasis(GP)}

The associated systemic comorbidities with duration and management were recorded in GP patients. (Table 4) Patients with longer duration of psoriasis( $\geq 10$ years) had higher prevalence of Diabetes mellitus(DM)(25\%),Hypertension(HTN)(52.8\%), Dyslipidemia(DL)(13.9\%) and Metabolic syndrome(MS)(13.9\%) which was statistically significant $(\mathrm{p}<0.01)$ for HTN and DM only. No significant difference was observed between the prevalence of comorbidities and psoriasis PASI severity.

Table 4. Systemic comorbidity profile in Elderly and Ultra elderly psoriatic groups.

\begin{tabular}{|l|c|c|c|c|c|}
\hline Characteristics & Elderly & Ultraelderly & & & \\
\hline
\end{tabular}




\begin{tabular}{|c|c|c|c|c|c|c|c|c|}
\hline & & Freq & $\%$ & Freq & $\%$ & Grand Total & $\%$ & $P$ value \\
\hline \multirow[b]{2}{*}{ Associated Comorbidity } & No & 56 & 39.7 & 7 & 31.8 & 63 & 38.7 & 0.24 \\
\hline & Yes & 85 & 60.3 & 15 & 68.2 & 100 & 61.3 & \\
\hline \multicolumn{2}{|c|}{ Arterial Hypertension(HTN) } & 67 & 47.5 & 14 & 63.6 & 81 & 49.7 & 0.12 \\
\hline & $<5$ years & 13 & 19.4 & 3 & 21.4 & 16 & 19.8 & \\
\hline & $5-10$ years & 24 & 35.8 & 2 & 9.09 & 26 & 32.1 & \\
\hline & $>10$ years & 30 & 44.8 & 9 & 40.9 & 39 & 48.2 & \\
\hline \multicolumn{9}{|c|}{ Anti HTN Drugs } \\
\hline \multicolumn{2}{|c|}{ Calcium Channel Blockers } & 52 & 77.6 & 13 & 92.9 & 65 & 80.3 & \\
\hline \multicolumn{2}{|l|}{ Diuretics } & 9 & 13.4 & 1 & 4.6 & 10 & 12.4 & \\
\hline \multicolumn{2}{|c|}{ Angiotensin Converting Enzyme Inhibitors } & 15 & 22.4 & 5 & 22.7 & 20 & 24.7 & \\
\hline \multicolumn{2}{|c|}{ Angiotensin Receptor Blockers } & 39 & 58.2 & 7 & 31.8 & 46 & 56.8 & \\
\hline \multicolumn{2}{|c|}{ Diabetes Mellitus type II(DM) } & 29 & 20.6 & 7 & 31.8 & 36 & 22.1 & \\
\hline & $<5$ years & 6 & 20.7 & 0 & 0 & 6 & 16.7 & \\
\hline & $5-10$ years & 15 & 51.7 & 0 & 0 & 15 & 9.2 & \\
\hline & $>10$ years & 8 & 27.6 & 7 & 31.82 & 15 & 9.2 & \\
\hline \multicolumn{9}{|c|}{ Hypoglycaemic Drugs } \\
\hline \multicolumn{2}{|c|}{ Metformin } & 25 & 86.2 & 7 & 31.8 & 32 & 88.9 & \\
\hline \multicolumn{2}{|c|}{ Sulfonylureas } & 21 & 72.4 & 7 & 31.8 & 28 & 77.8 & \\
\hline \multicolumn{2}{|c|}{ Thiozolididiones } & 7 & 24.1 & 3 & 13.6 & 10 & 27.8 & \\
\hline \multicolumn{2}{|l|}{ Acarbose } & 1 & 3.5 & 0 & 0 & 1 & 2.8 & \\
\hline \multicolumn{2}{|c|}{ Meglitides } & 6 & 20.7 & 2 & 9.1 & 8 & 22.2 & \\
\hline \multicolumn{2}{|l|}{ Insulin } & 1 & 3.5 & 0 & 0 & 1 & 2.8 & \\
\hline \multicolumn{2}{|c|}{ Dyslipidemia } & 33 & 23.4 & 9 & 41 & 42 & 25.8 & \\
\hline & $<5$ years & 5 & 15.2 & 1 & 1.1 & 6 & 14.3 & \\
\hline & $5-10$ years & 16 & 48.5 & 1 & 1.1 & 17 & 40.5 & \\
\hline & $>10$ years & 12 & 36.4 & 7 & 77.8 & 19 & 45.2 & \\
\hline \multicolumn{2}{|c|}{ Ischaemic Heart Disease } & 11 & 7.8 & 6 & 27.3 & 17 & 10.43 & \\
\hline & $<5$ years & 3 & 27.3 & 3 & 50 & 6 & 35.3 & \\
\hline & $5-10$ years & 4 & 36.4 & 0 & 0 & 4 & 23.5 & \\
\hline & $>10$ years & 4 & 36.4 & 3 & 50 & 7 & 41.2 & \\
\hline \multicolumn{2}{|c|}{ Metabolic syndrome } & 22 & 15.6 & 7 & 31.8 & 29 & 17.8 & \\
\hline \multicolumn{2}{|c|}{ Hypothyroidism } & 4 & 2.8 & 1 & 4.55 & 5 & 3.1 & \\
\hline & $<5$ years & 0 & & 0 & 0 & 0 & 0 & \\
\hline & $5-10$ years & 3 & 75 & 0 & 0 & 3 & 60 & \\
\hline & $>10$ years & 1 & 25 & 1 & 100 & 2 & 40 & \\
\hline \multicolumn{2}{|c|}{ Thyroxine } & 3 & 75 & 1 & 4.55 & 4 & 80 & \\
\hline \multicolumn{2}{|c|}{ Benign Prostatic Hyperplasia } & 5 & 3.6 & 1 & 4.55 & 6 & 5.2 & \\
\hline
\end{tabular}




\begin{tabular}{|c|c|c|c|c|c|c|c|}
\hline & $<5$ years & 2 & 40 & 1 & 100 & 3 & 50 \\
\hline & $5-10$ years & 1 & 20 & 0 & 0 & 1 & 16.7 \\
\hline & $>10$ years & 2 & 40 & 0 & 0 & 2 & 33.3 \\
\hline \multicolumn{2}{|c|}{ Athritis except Psoriatic arthritis } & 4 & 2.8 & 0 & 0 & 4 & 2.4 \\
\hline & $<5$ years & 1 & 25 & 0 & 0 & 1 & 25 \\
\hline & $5-10$ years & 1 & 25 & 0 & 0 & 1 & 25 \\
\hline & $>10$ years & 2 & 50 & 0 & 0 & 2 & 50 \\
\hline \multicolumn{2}{|l|}{ Renal disease } & 2 & 1.4 & 0 & 0 & 2 & 1.2 \\
\hline & $<5$ years & 0 & 0 & 0 & 0 & 0 & 0 \\
\hline & $5-10$ years & 1 & 50 & 0 & 0 & 1 & 50 \\
\hline & $>10$ years & 1 & 50 & 0 & 0 & 1 & 50 \\
\hline \multicolumn{2}{|l|}{ Others } & 8 & 5.7 & 2 & 9.1 & 10 & 6.1 \\
\hline & $<5$ years & 3 & 37.5 & 1 & 50 & 4 & 40 \\
\hline & $5-10$ years & 3 & 37.5 & 0 & 0 & 3 & 30 \\
\hline & $>10$ years & 2 & 25 & 1 & 50 & 3 & 30 \\
\hline
\end{tabular}

On comparing systemic comorbidities with remaining 963 controls(patients with skin disorders other than psoriasis), it was found that DL and MS was significantly $(\mathrm{p}<0.0001)$ more common in GP while DM more in controls $(\mathrm{p}<0.0001)$. (Figure 4)

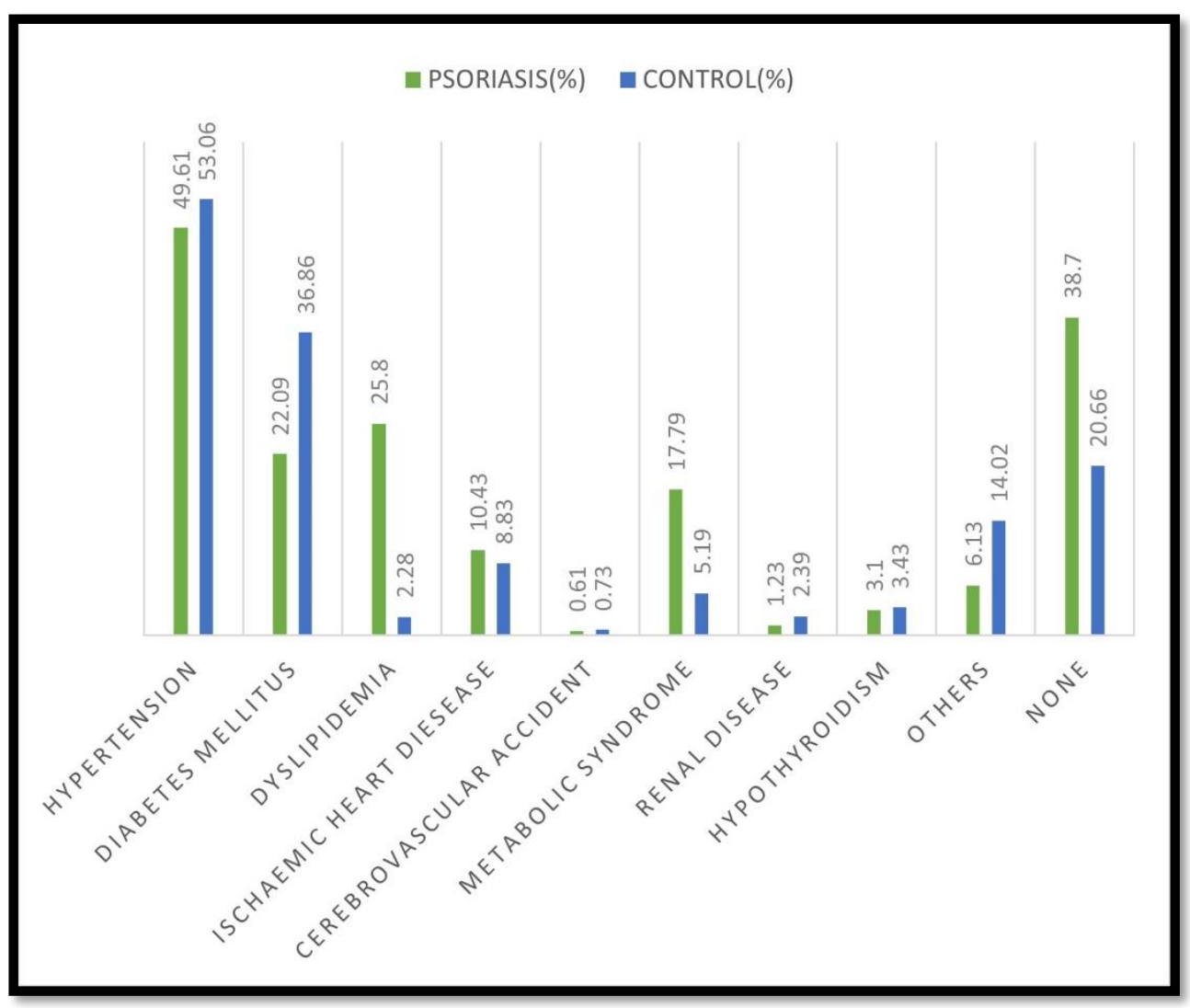

Figure 4. Systemic Comorbidities in Geriatric Psoriasis and Controls. 


\section{Discussion}

Worldwide studies have reported an increasing trend in GP prevalence(3.1-18.9\%) over the past 30 years $[6,13-18]$ with few demonstrating decreasing prevalence in individuals $>70$ years $[17,19]$. In our study, a higher psoriasis prevalence $(14.5 \%)$ was seen among the geriatrics $\geq 60$ years with eldest being 88 years. While most Western studies $[13,17,19,20]$ have used a cut off 'elderly age' at 65 years, we chose the cut off at 60 years as it's the retirement age as well as the 'Elderly age' adopted by the Indian Government [1]. Hence, GP prevalence has increased with rise in geriatric population.

In our study, GP prevalence was almost half( $8.3 \%)$ in UP as compared to $\mathrm{EP}(16.4 \%)$ which could be attributed to the progressive impairment of the immune system with age -'Immunosenescence' [16]. (Figure 1)

North Indian studies report adult psoriasis prevalence as $0.8-2.3 \%$; peak onset between third and fourth decades and a male:female ratio of 2.4:1 [4]. This ratio remained constant in our GP study(2.5:1) while Spanish GP study reported a lower 1.8:1 ratio [17].

Psoriasis has bimodal onset:early(20-30 years) and late( $>40$ years) [21] with a peak at 55 years [22]. Piaserico et al. [23] and Bedi et al. [24] reported psoriasis onset at 71 and 72 years respectively. In our study, $79.43 \% \mathrm{EP}$ and $77.91 \%$ UP had psoriasis onset within 10 years; that is around 55 years corresponding to late-onset among EP and around 68 years for UP. Kwon et al. [25] identified 'Elderly onset group' with onset age $>60$ years. Takeshita et al. also reported average age of GP onset at 68 years [26]. Probably psoriasis is 'Trimodal in onset' with a third peak around 68 years which needs further observation. The oldest reported age of psoriasis onset is 108 years [22] while it is 82 years from India [6].

According to BMI, $31.2 \%$ EP were obese vs $18.2 \%$ UP in our study. In United States(US), only $9.3 \%$ were obese, [26] while Spanish GP study reported normal, overweight and obese BMI in $24.3 \%, 31.4 \%$ and $44.3 \%$ respectively [17] accounting for regional constitutional genetic disparity [17].

A Multinational Assessment of Psoriasis and Psoriatic Arthritis survey from US reported a 2 year median delay from symptom onset to time of diagnosis and delayed dermatologist visit until a year [27]. Contrarily, $90.8 \%$ GP patients had visited Dermatologist within 6 months of psoriasis onset with 89.4\% EP and 100\% UP emphasizing easier Dermatologist access in India.

NPP accounts for $76-90 \%$ psoriatic cases $[17,25,28]$ as in our study $(90.2 \%)$, followed by $\mathrm{LPP}(6.7 \%)$ and guttate $(5 \%)$. Interestingly, UP did not present with unstable guttate, erythrodermic or pustular lesions. This difference was statistically significant suggesting stability of psoriatic plaques with Immunosenesence. (Table 2) Interestingly, inverse psoriasis was not reported in our study in spite obesity being common and implicated to increase its prevalence [22].

Nail involvement varies from $13-50 \%$ with cumulative lifetime increase to $80 \%-90 \%$ [11]. Kwon et al. reported higher nail involvement in elderly onset psoriasis(27.9\%) [25]. In our cohort, Nail involvement was seen in 37.6\% EP and 50\% UP in while Ferrandiz et al. reported a lower prevalence at $1.4 \%$ [11].

Scalp $(36.8 \%)$ was the most frequent site of psoriasis origin, followed by extremity $(19.3 \%)$,hand/foot(16.8\%),knee/elbow(14.3\%),face $(9.2 \%)$ and trunk $(4 \%)$ by Korean study [25]. Whereas we reported $43.6 \%$ palms/soles or both as initial site of involvement. Kumar et al. reported palms/soles were the first site of onset in 21\% of adult Palmoplantar psoriasis [28]. The relation between age of onset and initially affected body part has rarely been reported and further supporting studies could provide useful information for clinicians.

Psoriatic plaques are most frequently found on the extensor surfaces(elbow $/ \mathrm{knees}$ ) of adults [29] but palms \pm soles were most commonly affected in our study. 
In our study, PASI $<10$ was seen in $92.2 \%$ EP and $95.5 \%$ UP reiterating the observations by Kwon et al. [25] and Fernandes et al. [17] of psoriasis severity declining as age advanced [25].

Positive affection of first degree family relatives were observed in $28.6 \%$ in Spanish GP as opposed to a lower prevalence of $7.1 \%$ in EP and none in UP in our study $(\mathrm{p}<0.05)$. Lower incidence of family history in the elderly-onset group corresponded well with previous reports $[11,25]$ highlighting close association between earlier onset psoriasis, unstable lesions and higher incidence of family history [11]. This difference could be due to poor recall by UP or since late onset psoriasis is more stable due to Immunosenescence. Interestingly trauma/koebnerisation or infections exacerbating psoriasis was not seen in both groups as opposed to routinely seen in childhood or early onset psoriasis reiterating stability of GP [21,25].

Smoking and alcoholism were seen in 55.7\% each $>65$ years [17] while in our study, there were $20.25 \%$ smokers, $11.04 \%$ alcoholics and $22.09 \%$ tobacco chewers. This difference could be attributed to the cultural differences in study populations.

Concomitant skin disorder was observed in $31.8 \%$ GP cases. Superficial fungal infections(Dermatophytosis-50\%) was the most common reiterating the menace of dermatophytosis in India leaving no age group unaffected.

Mild Molin's extent [30,31] was outlined by Kwon et al. [25] along with Mild Haftek;s activity [32] by Pott's et al. [7], Kwon et al. [25] and our study. (Figure 5)

Kwon et al. [25] described 32(25.4\%), 50(39.7\%), 25(19.8\%) and 19(15.1\%) vs 15(9.2\%), $105(64.4 \%), 41(25.2 \%)$ and $2(1.23 \%)$ in our study to have none mild, moderate and severe symptoms respectively. We reported higher 'Improved'(55.2\% vs 30\%) and Wax and Waning'(23.3\% vs 7.4\%) subjective states as compared to Kwon et al. [25]. 


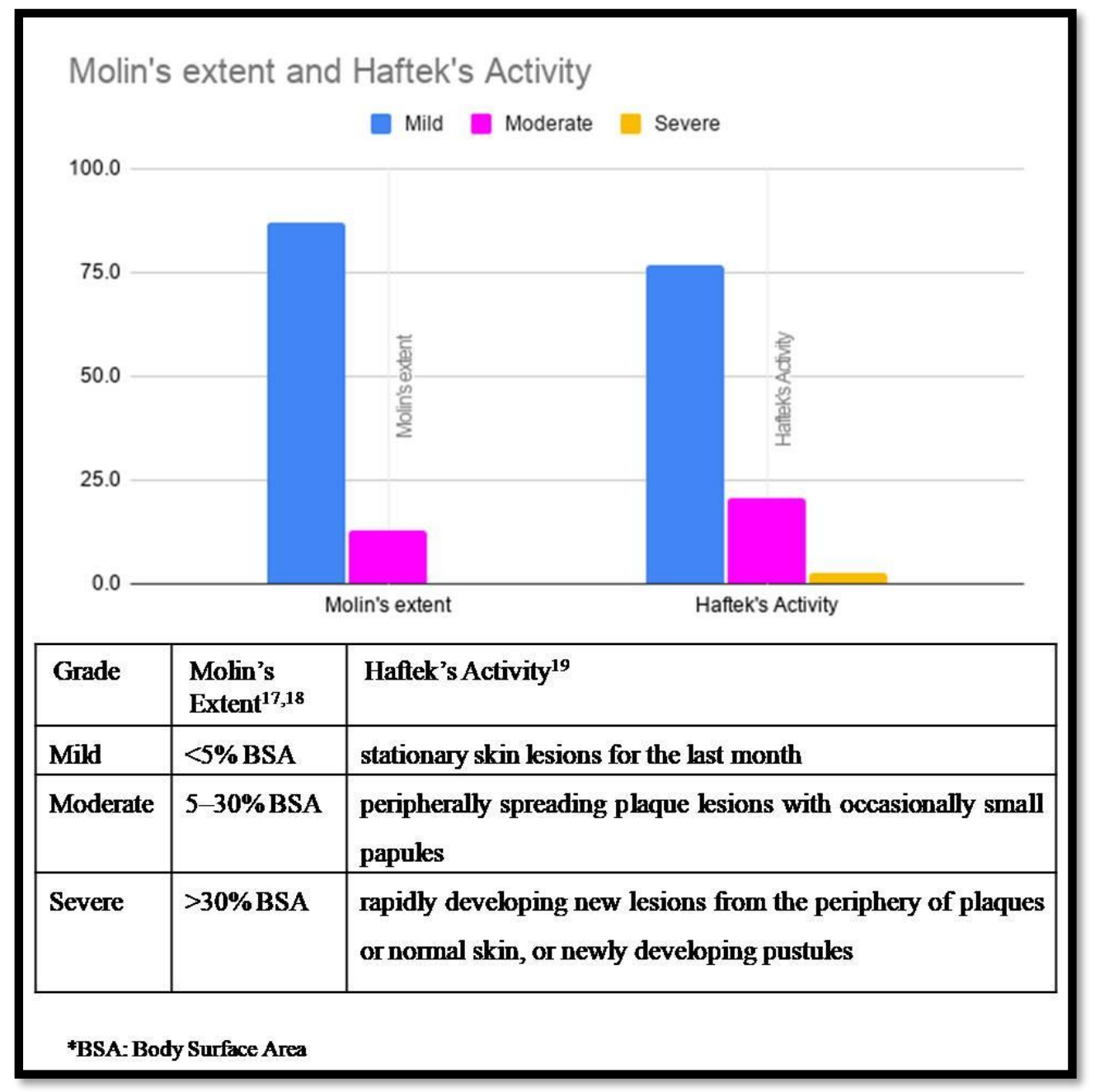

Figure 5. Psoriatic Activity

Although Psoriasis affects skin and joints primarily, [33] concurrent systemic illnesses with Psoriasis are termed as 'Comorbidity'. Genetic and environmental differences could account for 75\% GP having at least one comorbid condition by Lebwohl et al. [27] vs only $38.7 \%$ in our study.

Takeshita et al. reported $\operatorname{HTN}(67.6 \%)$; DL(59.9\%); DM(32.4\%) of which $23.5 \%$ had atherosclerotic outcomes [26]. In Spanish GP, HTN, DM and DL were observed in 55.7\%, $25.7 \%$ and $29 \%$ respectively similar to our study [17]. (Table 5)

Kim et al. in their analysis according to sex and age; found causal association between HTN and psoriasis risk, but HTN in $\geq 65$ years was not associated with psoriasis incidence. They concluded that increased prevalence of obesity, DM, or DL related to inflammation and oxidative stress increase the risk of HTN in young adults which are similar to psoriatic pathogenesis, whereas the pathophysiology of HTN in the elderly include age-related elastic tissue degradation and arterial calcium deposition [34].

Early onset psoriasis is an independent risk factor for cardiovascular disease, this risk is highest with severe psoriasis $[29,35]$. The relationship between psoriasis severity and comorbidities varies in different studies. In a Malaysian study, HTN, DM, DL and obesity were more frequent in patients presenting late-onset psoriasis with significantly fewer instances of familial psoriasis with no significant difference in the prevalence of comorbidities and psoriatic severity [36]. A large study involving 131,560 patients reported increased prevalence of obesity and DM in patients with severe psoriasis [37]. 
Increased age-adjusted relative risk for myocardial infarction was reported in a population-based cohort study involving 130,976 patients [37] as well as Gelfand et al. [35], Xiao et al. [38] and Sommer et al. [39]. However, Gisondi et al. [40] found no correlation between psoriasis severity and prevalence of MS consistent with our findings. Of note for these studies is the fact that none of these were studied predominantly in the elderly age group and the definitions adopted for psoriasis severity were varied and inconsistent. Other psoriasis associated comorbidities [7] like Irritable bowel disease, psoriatic arthritis, depression, hepatorenal diseases and malignancies are associated were not observed in our study.

On comparing systemic comorbidities with remaining 963 controls, it was found that DL and MS were significantly $(p<0.0001)$ more common among GP consistent with other studies $[35,37,41]$ while interestingly DM was more common in controls $(\mathrm{p}<0.0001)$. (Table 5)

Table 5. Studies describing systemic comorbidities and Psoriasis.

\begin{tabular}{|c|c|c|c|c|c|c|c|c|c|c|c|c|c|}
\hline \multirow[b]{2}{*}{$\begin{array}{l}\text { Ye } \\
\text { ar }\end{array}$} & \multirow[b]{2}{*}{ Author } & \multirow[b]{2}{*}{$\begin{array}{c}\text { Coun- } \\
\text { try }\end{array}$} & \multirow{2}{*}{$\begin{array}{c}\text { Age } \\
\text { grp(year } \\
\text { s) }\end{array}$} & \multicolumn{2}{|c|}{$\begin{array}{l}\text { Hyperten- } \\
\text { sion }\end{array}$} & \multicolumn{2}{|c|}{$\begin{array}{l}\text { Diabetes Melli- } \\
\text { tus type II }\end{array}$} & \multicolumn{2}{|c|}{$\begin{array}{c}\text { Dyslipidemi } \\
\text { a }\end{array}$} & \multicolumn{2}{|c|}{$\begin{array}{c}\text { Ischemic Heart } \\
\text { Disease }\end{array}$} & \multicolumn{2}{|c|}{$\begin{array}{l}\text { Metabolic } \\
\text { syndrome }\end{array}$} \\
\hline & & & & $\begin{array}{l}\text { Pso- } \\
\text { riasis }\end{array}$ & $\begin{array}{l}\text { Con } \\
\text { trol }\end{array}$ & $\begin{array}{l}\text { Psoria- } \\
\text { sis }\end{array}$ & $\begin{array}{l}\text { Con- } \\
\text { trol }\end{array}$ & $\begin{array}{l}\text { Pso- } \\
\text { riasis }\end{array}$ & $\begin{array}{l}\text { Con } \\
\text { trol }\end{array}$ & $\begin{array}{l}\text { Psori- } \\
\text { asis }\end{array}$ & $\begin{array}{l}\text { Con- } \\
\text { trol }\end{array}$ & $\begin{array}{l}\text { Psori- } \\
\text { asis }\end{array}$ & $\begin{array}{l}\text { Con- } \\
\text { trol }\end{array}$ \\
\hline $\begin{array}{l}19 \\
85\end{array}$ & $\begin{array}{c}\text { Henseler et } \\
\text { al. }^{44}\end{array}$ & $\begin{array}{l}\text { Ger- } \\
\text { many }\end{array}$ & N/A & 1.9 & 0.8 & 2.1 & 1.1 & - & - & - & - & - & - \\
\hline $\begin{array}{l}20 \\
02 \\
\end{array}$ & $\begin{array}{c}\text { Niemann et } \\
\text { al. }^{37} \\
\end{array}$ & USA & $20-90$ & 34.7 & 11.9 & 11.5 & 3.3 & 10.7 & 3.3 & - & - & - & - \\
\hline $\begin{array}{l}20 \\
06\end{array}$ & Gelfand et al. ${ }^{35}$ & USA & $31-63$ & 14.7 & 11.9 & 4.4 & 3.3 & 4.6 & 3.3 & 1.8 & 1.4 & - & - \\
\hline $\begin{array}{l}20 \\
12\end{array}$ & Mazlin et al.36 & $\begin{array}{l}\text { Malay- } \\
\text { sia }\end{array}$ & $>18$ & 33.2 & - & 17.7 & - & 17.8 & - & 5.8 & - & - & - \\
\hline $\begin{array}{l}20 \\
12 \\
\end{array}$ & $\begin{array}{l}\text { Fernandez- } \\
\text { Torres et al. }{ }^{17}\end{array}$ & Spain & $>65$ & 55.7 & - & 25.7 & - & 29 & - & - & - & - & - \\
\hline $\begin{array}{l}20 \\
15 \\
\end{array}$ & Takshita et al. ${ }^{26}$ & USA & & 67.6 & - & 32.4 & - & 59.9 & - & 23.5 & - & - & - \\
\hline $\begin{array}{l}20 \\
16 \\
\end{array}$ & Phan C et al. ${ }^{41}$ & France & 48.7 avg & 26.1 & - & 11 & - & 27.5 & - & - & - & - & - \\
\hline $\begin{array}{l}20 \\
18\end{array}$ & $\begin{array}{c}\text { Feldman et } \\
\text { al. } .^{45}\end{array}$ & USA & $>20$ & 39.7 & 33.7 & 15.5 & 13 & 38.7 & 33 & 10.7 & 8.7 & - & - \\
\hline $\begin{array}{l}20 \\
18 \\
\end{array}$ & Kim et al. ${ }^{34}$ & $\begin{array}{l}\text { South } \\
\text { Korea }\end{array}$ & $>20$ & 5 & 3.3 & - & - & - & - & - & - & - & - \\
\hline $\begin{array}{l}20 \\
20\end{array}$ & $\begin{array}{c}\text { Yildizhan et } \\
\text { al. }^{16}\end{array}$ & Turkey & $\geq 65$ & 57.3 & - & 33.7 & - & 22.5 & - & 22.5 & - & - & - \\
\hline $\begin{array}{l}20 \\
20\end{array}$ & Our study & India & $>60$ & 49.6 & 53.1 & 22.8 & 37 & 25.8 & 2.3 & 10.4 & 8.8 & 17.8 & 5.2 \\
\hline
\end{tabular}

We observed increased prevalence of HTN, DM and DL if psoriasis duration was $>10$ years reinterating psoriatic march triggering systemic inflammation and atherosclerosis; or may be age-associated coincidence.

Angiotensin-converting enzyme inhibitors(ACEI), angiotensin-converting enzyme blockers(ARB),Calcium Channel Blockers(CCB),Thiazides, antimalarials, lithium and nonsteroidal anti inflammatory drugs are known to induce and exacerbate psoriasis [29]. Interestingly, in our study, none were on $§$ blockers known to exacerbate GP [34]. Although theoretically, drug induced psoriasis is common [37] in geriatrics owing to polypharmacy, no such causal attribution could be established in our study despite CCB instead of $\beta$ blockers being widely used to treat HTN in our institute. 
Systemic therapy must take into consideration the patients' comorbidities(to identify contraindications) and co-medications(to avoid drug interactions). Comorbidities not only reduce therapeutic options, but can potentially be aggravated by anti-psoriatic treatment. Acitretin and Cyclosporine can increase serum triglycerides and cholesterol, negatively influencing DL linked to MS [33]. In our study, acitretin(31.8\%) and cyclosporine $(9.1 \%)$ was used in EP and PASI75 was achieved in $61.8 \%$ and $66.7 \%$ respectively in absence of any side-effects.

In a Spanish study, 54.3\% GP were relieved with topicals alone, while conventional systemic therapy and biologics were required by $31.4 \%$ and $14.3 \%$ respectively [17]. Takeshita et al. [26] found oral methotrexate to be used most commonly for moderatesevere psoriasis, followed by biologics [25]. In our study ,63.8\% were controlled with topicals alone while $36.2 \%$ required conventional agents to attain PASI75, while none required biologicals. Phototherapy was received by only one EP indicating that although efficacious and safe, repeated weekly multi-hospital visits by a relatively morbid geriatric group was not preferred.

Our findings suggest a trimodal age of psoriatic onset at 68 years. Mental stress $(41.8 \%)$ and Seasonal exacerbation(50\%) are common psoriatic triggers in EP and UP respectively $(\mathrm{p}<0.05)$. As age advances, GP prevalence increases; psoriasis severity decreases, unstable(guttate,erythrodermic,pustular) lesions decrease, soles more frequently involved and less familial occurrence. $\operatorname{HTN}(49.7 \%)$ and DL(25.8\%) are the most common associated comorbidities and its prevalence increases if psoriasis duration $>10$ years. Inspite of polypharmacy, drug aggravated psoriasis could not be linked in either groups and with psoriasis severity. Topicals form the mainstay of GP management. Oral Methotrexate is most efficacious for systemic therapy. This is the first Indian study to describe the association between systemic comorbidities and their medication use, and risk of psoriasis incidence in elderly Indian population.

Limitations of this study include its observational nature, heterogeneous duration of treatment, non-representation of community GP prevalence being a hospital-based study. The findings are solely based on patient's history and available medical records. Selection bias could occur as comorbid patients more likely visit hospital. A large, multi-centre, prospective case-control study would help determine the relative risk for comorbidities among GP and various epidemiological and genetic trends.

The perception of psoriasis being merely 'skin deep' has to change among dermatologists and non-dermatologists alike. Active long-term screening for cardiovascular comorbidities along with proactive management of modifiable risk factors with appropriate subspeciality referrals in all adult psoriasis is highly recommended. Thus, physicians must be familiar with GP and provide patient-centered, cost-effective and practical management.

\section{Data Privacy Statement}

Due to the nature of this research, participants of this study did not agree for their data to be shared publicly, so supporting data is not available.

\section{References}

[1] Khosravi H and Butler DC. An Ultra Elderly Presentation of Psoriasis: An Emerging Population. Arch Med. $2016,8: 6$.

[2] Elderly in India-Profile and Programmes 2016. New Delhi: Ministry of Statistics and Programme Implementation. Government of India. 2016.

[3] Khan S and Itrat M. Current Issues in Geriatric Health Care in India-A Review. J Community Med Health Care. $2016 ; 1$ (1): 1003.

[4] Balato N, Patruno C, Napolitano M, et al. Managing moderate-to-severe psoriasis in the elderly. Drugs Aging. 2014;31(4):233-8.

[5] Farber EM, Nall ML. The natural history of psoriasis in 5,600 patients. Dermatologica 1974; 148: 1-18.

[6] Dogra S, Mahajan R. Psoriasis: Epidemiology, clinical features, co-morbidities, and clinical scoring. Indian Dermatol Online J. 2016 Nov-Dec;7(6):471-480.

[7] Thappa DM, Munisamy M. Research on psoriasis in India: Where do we stand? Indian J Med Res. 2017 Aug;146(2):147-149. 
[8] G. Venkata Ramana, P. Malini, N. Arun, Anand B. Patterns of psoriasis in patients attending DVL OPD at osmania general hospital - a prevalence study. International Journal of Contemporary Medical Research 2017;4(9):1906-1908.

[9] Potts GA, Hurley MY. Psoriasis in the geriatric population. Clin Geriatr Med. 2013 May;29(2):373-95. Doi: 10.1016/j.cger.2013.01.004. Pubmed PMID: 23571034.

[10] Bassukas, I., Mavridou, K., Evangelou, T., \& Gaitanis, G. (2011). The prevalence of psoriasis among elderly individuals: more questions than answers. Ageing Research, 2(1), e1.

[11] Phan C, Sigal ML, Estève E, et al. Psoriasis in the elderly: epidemiological and clinical aspects, and evaluation of patients with very late onset psoriasis. J Eur Acad Dermatol Venereol. 2016;30(1):78-82. Doi:10.1111/jdv.12850

[12] Youn JI, Park BS, Park SB et al. Characterization of early and late onset psoriasis in the Korean population. J Dermatol 1999; 26: 647-652.

[13] Ferrandiz C, Pujol RM, Garcia-Patos V et al. Psoriasis of early and late onset: a clinical and epidemiologic study from Spain. J Am Acad Dermatol 2002; 46: 867-873

[14] Kimmel WG and Lebwohl M. Bhutani T, Liao Wilson, Nakamura M ed. Psoriasis overview and diagnosis. Evidence based Psoriasis. Springer, New Delhi 2019, CHP 1 pg. 2.

[15] Aziz N, Kallur SD, Nirmalan PK. Implications of the revised consensus body mass indices for asian Indians on clinical obstetric practice. J Clin Diagn Res. 2014;8(5):OC01-OC3.

[16] Palo SK, Swain S, Priyadarshini S, Behera B, Pati S. Epidemiology of obesity and its related morbidities among rural population attending a primary health centre of Odisha, India. J Family Med Prim Care. 2019;8(1):203-208.

[17] Molin L. Climate therapy for Swedish psoriatics on Hvar, Yugoslavia. Acta Derm Venereol 1972; 52: $155-160$.

[18] Molin L. Psoriasis. Acta Derm Venerol 1973; 53: 7-36.

[19] Haftek M, Glinski W, Jablonska S, et al. T lymphocyte E rosette function during photochemotherapy (PUVA) of psoriasis. J Invest Dermatol 1979; 72: 214-218.

[20] Yosipovitch G, Tang MB. Practical management of psoriasis in the elderly: epidemiology, clinical aspects, quality of life, patient education and treatment options. Drugs Aging. 2002;19(11):847-63.

[21] Gligora M, árzensek J, Rems d, Troskot n, Banjanin M. Psoriasis in the third age. Ácta derm Venereol (stockh) 1989;146:168-70.

[22] Yap KB, siew MG, Goh cl. Pattern of skin diseases in the elderly seen at the national skin centre (singapore) in 1990. Singapore Med J 1994; 35:147-50.

[23] Liao YH, chen $\mathrm{KH}$, Tseng MP, sun cc. Pattern of skin diseases in a geriatric patient group in Taiwan: a 7-year survey from the outpatient clinic of a University Medical centre. Dermatology 2001;203:308-13.

[24] Mcfadden n, Hande Ko. Á survey of elderly new patients at a dermatology outpatient clinic. Ácta derm Venereol 1989;69:2602.

[25] Bell LM, Sedlack R, Beard CM, et al. Incidence of psoriasis in Rochester, Minn, 1980-1983. Arch Dermatol 1991; $127: 1184-1187$.

[26] Kalay Yildizhan, Incilay \& Sürgün, Ece \& Kundakc1, Nihal. Epidemiological and clinical characteristics, treatments, and comorbidities in elderly patients with psoriasis and the evaluation of patients according to the age of onset. Turk Geriatri Dergisi. 2020.10.31086/tigeri.2020.156.

[27] Fernandez-Torres RM, Paradela S, Fonseca E. Psoriasis in patients older than 65 years. A comparative study with younger adult psoriatic patients. J Nutr Health Aging 2012;16:586-91.

[28] Ayanlowo O, Akinkugbe A. Clinical pattern of psoriasis in patients seen at a tertiary hospital in Nigeria. J Clin Sci 2016;13:13742.

[29] Gelfand JM, Weinstein R, Porter SB, Neimann AL, Berlin JA, Margolis DJ. Prevalence and Treatment of Psoriasis in the United Kingdom: A Population-Based Study. Arch Dermatol. 2005;141(12):1537-1541.

[30] Henseler T, Christophers E. Psoriasis of early and late onset: characterization of two types of psoriasis vulgaris. J Am Acad Dermatol. 1985;13(3):450-456.

[31] Piaserico S, Conti A, Lo Console F, et al. Efficacy and safety of systemic treatments for psoriasis in elderly patients. Acta Derm Venereol. 2014;94(3):293-297.

[32] Bedi TR. Clinical profile of psoriasis in North India. Indian J Dermatol Venereol Leprol. 1995 Jul-Aug;61(4):202-5.

[33] Kwon HH, Kwon IH, Youn JI. Clinical study of psoriasis occurring over the age of 60 years: is elderly-onset psoriasis a distinct subtype? Int J Dermatol. 2012 Jan;51(1):53-8.

[34] Takeshita J, Gelfand JM, Li P, et al. Psoriasis in the US Medicare population: prevalence, treatment, and factors associated with biologic use [published online July 27, 2015]. J Invest Dermatol. 2015;135:2955-2963. doi:10.1038/jid.2015.296.

[35] Lebwohl MG, Bachelez H, Barker J, et al. Patient perspectives in the management of psoriasis: results from the population-based Multinational Assessment of Psoriasis and Psoriatic Arthritis Survey. J Am Acad Dermatol. 2014;70(5):871-81.e830.

[36] Kumar S, Nayak CS, Padhi T, Rao G, Rao A, Sharma VK, Srinivas CR. Epidemiological pattern of psoriasis, vitiligo and atopic dermatitis in India: Hospital-based point prevalence. Indian Dermatol Online J. 2014 Nov;5(Suppl 1):S6-8.

[37] Kimmel WG and Lebwohl M. Bhutani T, Liao Wilson, Nakamura M ed. Psoriasis overview and diagnosis. Evidence based Psoriasis. Springer, New Delhi 2019, CHP 1 pg. 2

[38] Aurangabadkar SJ. Comorbidities in psoriasis. Indian J Dermatol Venereol Leprol. 2013 Jul;79 Suppl 7:S10-7.

[39] Gelfand JM, Neimann AL, Shin DB, Wang X, Margolis DJ, Troxel AB. Risk of myocardial infarction in patients with psoriasis. JAMA. 2006;296(14):1735-1741. 
[40] Kim HN, Han K, Song SW, Lee JH. Hypertension and risk of psoriasis incidence: An 11-year nationwide population-based cohort study. PLoS One. 2018;13(8):e0202854. Published 2018 Aug 24. doi:10.1371/journal.pone.0202854

[41] Mazlin MB, Chang CC, Baba R. Comorbidities associated with psoriasis - data from the Malaysian psoriasis registry. Med J Malaysia 2012;67:518-21.

[42] Neimann AL, Shin DB, Wang X, Margolis DJ, Troxel AB, Gelfand JM. Prevalence of cardiovascular risk factors in patients with psoriasis. J Am Acad Dermatol. 2006;55(5):829-835.

[43] Xiao J, Chen LH, Tu YT, et al. Prevalence of myocardial infarction in patients with psoriasis in central China. J Eur Acad Dermatol Venereol 2009; 23:1311.

[44] Sommer DM, Jenisch S, Suchan M, et al. Increased prevalence of the metabolic syndrome in patients with moderate to severe psoriasis. Arch Dermatol Res 2006; 298:321.

[45] Gisondi P, Targher G, Zoppini G, Girolomoni G. Non-alcoholic fatty liver disease in patients with chronic plaque psoriasis. J Hepatol 2009; 51:758.

[46] Feldman SR, Hur P, Zhao Y, et al. Incidence rates of comorbidities among patients with psoriasis in the United States. Dermatol Online J. 2018;24(10):13030/qt2m18n6vj. Published 2018 Oct 15.

[47] Phan C, Sigal ML, Lhafa M, et al. Metabolic comorbidities and hypertension in psoriasis patients in France. Comparisons with French national databases. Ann Dermatol Venereol. 2016;143(4):264-274. doi:10.1016/j.annder.2015.06.024. 